\title{
2. Overview of the Anker living wage methodology
}

\section{PART I. BACKGROUND}

This manual describes how to estimate a living wage using the Anker methodology. There are many new aspects to this methodology. The current chapter provides a brief description of the methodology, and what is new and different about it compared with other common methodologies for developing countries. Table 2A.1 in Appendix 2.1 provides a summary of the primary and secondary data needed to estimate a living wage using this methodology.

Some key features of the methodology that make it practical, realistic, and an improvement on other methodologies for developing countries include the following (see Anker, 2011 for a review of other living wage methodologies).

- Greater use is made of normative standards than other typical living wage methodologies for developing countries.

- Transparency is emphasized with assumptions and calculations clearly indicated in a living wage report so that it is more than simply a number.

- Judicious mix is made of rapid assessment methods and secondary data to make it possible to estimate credible, location-specific living wages in a practical way.

- Low-cost nutritious model diet is developed that is consistent with local food habits and WHO/FAO nutrition guidelines to ensure that there are sufficient calories and acceptable amounts of proteins, fats, carbohydrates, and fruits and vegetables. This is done using Excel programs developed for this purpose.

- Cost of the model diet is estimated using local food prices collected through a new survey of local food markets that mimics the way that cost-conscious workers buy food.

- Housing costs are estimated separately using a local healthy housing standard that is established based on international minimum standards and local housing conditions with the cost of such housing determined based on visits to local housing. 
- Secondary data are used to estimate the cost of all other essential needs, and are carefully scrutinized and adjusted as necessary. This result is checked against new primary data on local health care and education costs collected using rapid assessment methods to help ensure that the living wage includes sufficient funds for these human rights.

- Family size and number of workers per family used to estimate a living wage are location-specific as they are determined based on secondary data for the location.

- Separate living wages are estimated for rural and urban areas rather than using one living wage for an entire country. In larger countries, separate estimates are made for different regions and major cities.

- Provision of social goods by the state is allowed to reduce the living wage. For example, when free meals are provided at school, the cost of the living wage model diet is reduced because fewer meals need to be prepared at home. The post checks on health care and education are affected by the cost, quality and availability of public services.

- Mandatory payroll deductions and income tax are taken into consideration to ensure that workers have sufficient take home pay to be able to afford a basic but decent standard of living.

- Guidelines are provided on how to measure prevailing wages so that they can be compared with a living wage and so learn if workers receive a living wage and employers pay a living wage. This includes detailed guidelines on how to value in kind benefits and cash allowances.

\section{PART II. DESCRIPTION OF LIVING WAGE METHODOLOGY}

\subsection{How a Living Wage is Estimated}

\subsubsection{Estimating cost of a basic but decent living standard for a reference size family}

Estimating a living wage begins by estimating the cost of a basic but decent life style for a worker and his/her family. This involves adding up the cost of three expenditure groups: food (for a low-cost nutritious diet), housing (for basic healthy housing), and other essential expenses for a family, and then adding a small margin for sustainability and emergencies. This is illustrated in Figure 2.1. 


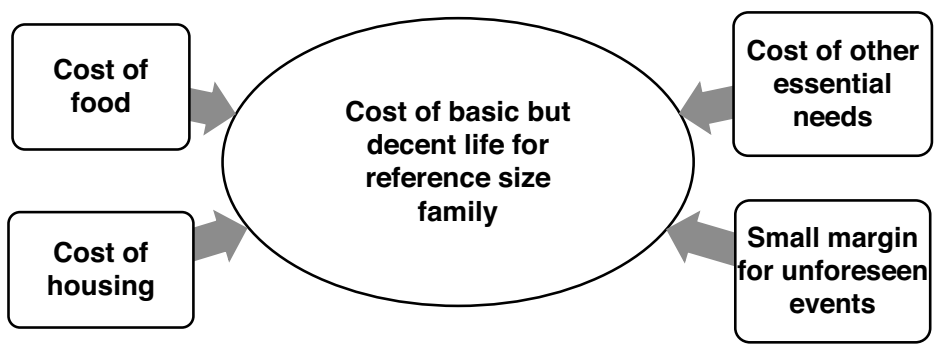

Figure 2.1 Cost of a basic but decent life for a family

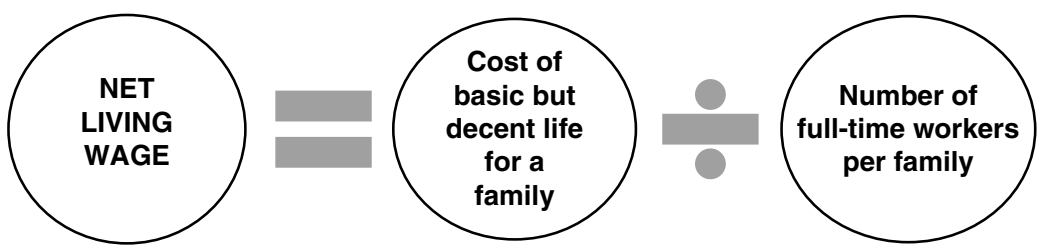

Figure 2.2 From cost of basic but decent life to net living wage

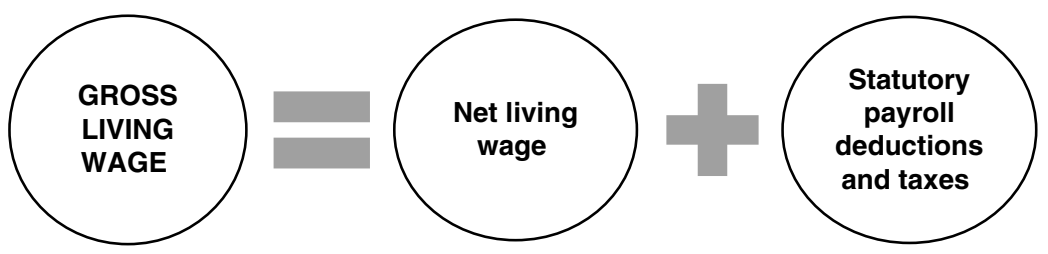

Figure 2.3 From net living wage to gross living wage

\subsubsection{Going from cost of a basic but decent life to a net living wage}

The next step defrays the cost of a basic but decent life for the reference size family over the number of workers per reference size family (Figure 2.2), which is always between one and two full-time workers per couple, and which depends on local conditions as regards labor force participation rates, unemployment rates, and part-time employment rates.

\subsubsection{Going from net living wage to gross living wage}

The gross pay required for workers to have sufficient take home pay is calculated by adding statutory payroll deductions and income tax that would be assessed on a living wage (Figure 2.3). Workers need to end up with sufficient take home pay to afford a basic but decent standard of living. 


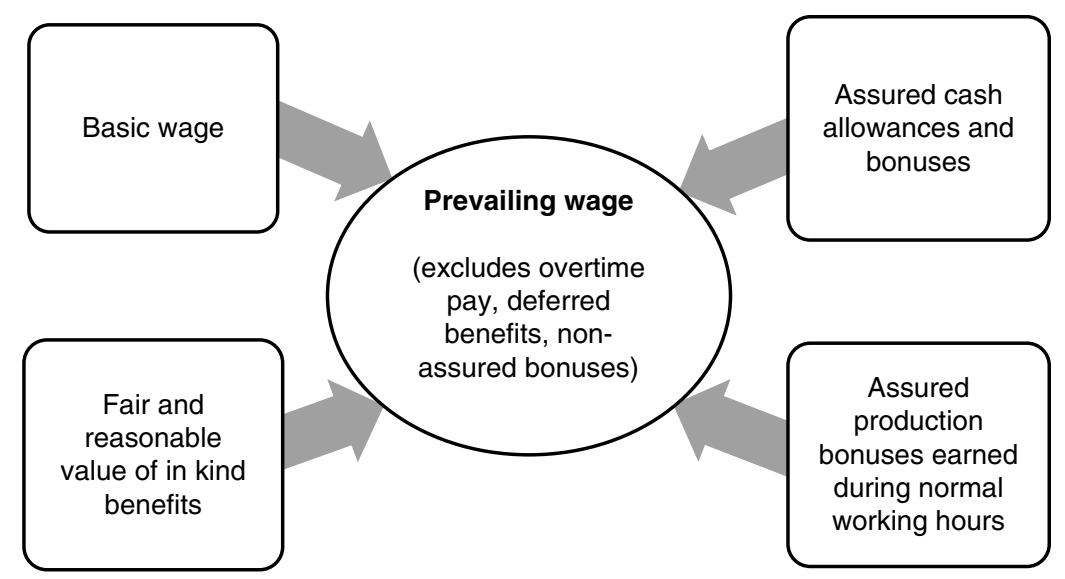

Figure 2.4 Determining prevailing wage in an establishment or industry and so if workers are paid a living wage

\subsubsection{Determining prevailing wages and whether workers are paid a living wage}

Estimating a living wage provides one side of an equation for comparing current wages with a living wage and determining if workers earn a living wage. The other side of the equation is prevailing wages earned during normal working hours (Figure 2.4).

Determining prevailing wages is not as simple as it may seem at first glance because remuneration comes in many different forms. Prevailing wages are determined by adding up the value of all forms of remuneration using guidelines described in this manual regarding which forms of remuneration should be included and how each of these should be valued for comparison with a living wage. Some forms of remuneration such as overtime and deferred benefits are excluded. Special rules are provided for how to value in kind benefits because of their controversial nature.

\subsection{Use of Three Main Costs - a Practical but Rigorous Approach}

As illustrated in Figure 2.1, the cost of a basic but decent life is estimated using three expense components - food, housing, and other essential needs. A small margin is added for sustainability and unforeseen events. The use of three cost components to estimate a living wage is a practical compromise between listing and pricing the cost of each and every family need, as was common 100 years ago, and the use of two cost components (food and other essential needs) as is common in most other living wage 
and poverty line estimates today for developing countries. The main disadvantages of the first approach are that it is very time consuming to create such a list and virtually impossible to obtain agreement on the necessity and quality of each and every item. The main disadvantage of the second approach is that the 'other essential needs' category has no normative basis despite the fact that it almost always represents well over one-half of all expenditures and this makes it impossible to understand what standard of living is implied by a living wage or whether it is even close to being decent.

Our methodology, which estimates housing costs separately, is a compromise between the two approaches noted above. It has several important advantages. First, directly estimating the cost of housing based on a housing standard, significantly increases the normative basis of the living wage estimate. It ensures that workers can afford decent housing. Second, it greatly decreases the size of the opaque 'other essential needs' category. This helps stakeholders and others to understand the basic but decent standard of living that the living wage is based on. Our methodology also uses post checks with adjustments when necessary to ensure that decent education and medical care can be afforded on a living wage.

\subsubsection{Estimating food cost using a low-cost nutritious diet and local food prices}

Food is almost always the largest expense in developing countries for a worker and his/her family. For this reason, a good deal of attention is paid in our methodology to developing an appropriate model diet and estimating its cost. Food costs are based on the cost of a low-cost nutritious model diet that is in keeping with local food preferences. Key features of our methodology for estimating food costs include:

1. The model diet must meet FAO and WHO nutritional guidelines as regards calories, macronutrients, and fruits and vegetables. Almost all other living wage and poverty line methodologies for developing countries use a model diet that only ensures sufficient calories.

2. Two Excel spreadsheets were developed (and are available on the Edward Elgar website) to assist researchers in creating an appropriate model diet that is nutritious, consistent with local food preferences, and relatively inexpensive for a nutritious diet.

3. The cost of the model diet is estimated using local food prices that workers typically pay. These food prices are determined based on a new survey of local markets where workers typically shop. 


\subsubsection{Estimating housing costs using international healthy housing standards, local housing conditions, and local housing costs}

Housing is usually the second largest expense for a worker and family in developing countries. Housing costs are estimated separately. This is in contrast to most other living wage and poverty line methodologies for developing countries that estimate all non-food costs (including housing) in one go. In our methodology, a local standard for healthy housing is set based on international and national standards, and local housing conditions. The cost of renting a dwelling that meets this basic standard is then estimated based on visits to a range of acceptable and unacceptable rental homes in the location. ${ }^{1}$

There are many advantages to this approach including:

1. Ensuring that workers can afford decent housing on a living wage (in contrast other typical methods for developing countries usually replicate the current poor housing conditions many workers now have). This also makes it much easier to estimate different living wages within countries, because housing is almost always the main reason for differences in living costs across locations within countries.

2. Increasing transparency, since a living wage is based on normative standards for food and housing which are the two largest expenditure groups in developing countries and almost always well over half of all expenditures.

\subsubsection{Estimating other essential expenses using secondary data}

While the estimate of both food and housing costs (usually the two largest household expenses in developing countries) are based on normative standards, it would be too difficult and time consuming to estimate the cost of all other expenses using normative standards, because this would require listing and obtaining agreement on each and every item needed by a family as regards quantities and qualities. Nor would this be practical. Therefore, our methodology relies primarily on secondary data from a recent household expenditure survey to estimate the cost of other essential expenses.

The cost of other essential expenses is estimated by multiplying the ratio of non-food and non-housing expenditures to food expenditures from a recent household expenditure survey by the cost of the living wage model diet. This is a simple, quick and practical way to estimate the cost of other essential expenses and is similar to the typical approach used by other living wage and poverty line methodologies for developing countries to estimate all non-food costs. However, there are some major differences. 
1. First, and most importantly, the 'other essential expenses' component in our methodology is much smaller than in most other typical methodologies for developing countries, because ours does not include housing. This increases the extent to which our living wage estimate is based on normative standards. This also increases cross-country comparability because national statistical offices differ in how they measure housing expenditure, with somewhat less than half the countries totally ignoring the cost or value of owner-occupied housing.

2. Second, our methodology closely scrutinizes how the household expenditure data used to estimate 'other essential needs' are classified and measured and makes adjustments whenever necessary. This is important because there are differences in how countries measure and classify household expenditure data, and these can affect the non-food/ non-housing to food ratio used to estimate other essential needs.

3. Third, amounts for health care and education included in a preliminary estimate of the cost of other essential needs are checked against information on the cost of decent education and health care collected in new fieldwork, with amounts for these increased when necessary.

2.2.3.1 Post checks for health care and education Health care and education are considered as human rights around the world. For this reason, they are given special attention in our methodology to make sure that sufficient amounts are included in the living wage estimate for decent education of children and health care. This has the advantage of further increasing the normative basis of a living wage estimate as well as its transparency. There are two main steps to these post checks:

1. First, information is collected in new fieldwork on the local cost of acceptable education and health care.

2. Second, costs of decent education and health care according to this new fieldwork are compared with amounts included for them in the preliminary estimate of non-food and non-housing costs with amounts for these increased when necessary.

\subsection{Adding Small Margin for Sustainability and Unforeseen Events}

A small margin is added to the cost of food, housing and other essential needs to allow for unforeseen events. This small margin is included in our methodology to ensure that workers earning a living wage are not easily plunged into poverty from which they may never be able to get out by unforeseen events such as accident or illness. 


\subsection{Reference Family Size}

Determining the reference family size to be supported by a living wage is very important because a living wage is a family wage. Our methodology allows reference family size to vary by country and location depending on average household size and total fertility rate and child mortality rate in the location, with different reference family sizes for rural and urban areas common.

\subsection{Number of Workers per Family}

Most other living wage methodologies for developing countries assume either one or two workers per family (Anker, 2011). Neither assumption is realistic in the twenty-first century. First, many women are in the labor force all over the world, so the assumption of one (usually male) breadwinner per family is not realistic. Second, not all adult family members work full-time - some are unable to find work, some need or want to stay home for various reasons, and some work part-time. This means that an assumption of two full-time workers per family is not realistic. Therefore, the number of workers per family in our methodology is always between one and two. Our methodology allows the number of workers per family to vary by country and location based on labor force participation rates, unemployment rates, and part-time employment rates.

\subsection{Statutory Deductions from Pay: Gross Pay and Net Pay}

Up to this point, a living wage estimate was concerned with the income that a family needs for a basic but decent life. This is the disposable income or take home pay required. Yet, workers in most countries (even workers with low pay) have statutory payroll deductions (e.g. social security taxes, contributions to national health systems, union fees) and sometimes income taxes to pay. Therefore, in order for workers to have enough net pay (after deductions), statutory deductions that would be assessed to workers earning a living wage need to be added to the net living wage estimate to get a gross living wage estimate. Other living wage methodologies for developing countries do not always address this issue. Our experience indicates that it is important to explicitly take into consideration statutory deductions from pay - otherwise they are too easily forgotten. 


\subsection{Need for More than One Living Wage per Country}

Cost of a basic but decent life style is different for rural and urban areas in almost all countries. Housing costs are often very different, as are the patterns of expenses. Therefore, it is not reasonable to have one living wage estimate applied to an entire country. There should be at a minimum separate living wages for rural and urban areas. Larger countries require separate living wage estimates for different regions and for different major cities.

\subsection{Estimating Prevailing Wages and Gaps to a Living Wage}

Determining the gap between prevailing wages and a living wage is often the most important reason for doing a living wage study. Companies, standard setting organizations, governments, trade unions, international organizations, NGOs and the public are interested in knowing this gap.

Our living wage methodology separates the task of estimating a living wage from the task of determining prevailing wages and so whether a living wage is paid in an industry or by an employer and the size of the gap between prevailing wages and a living wage. Guidelines are provided on how to measure prevailing wages for comparison to a living wage. This is not as straightforward as it might seem, because remuneration has many components (e.g. basic wage, cash allowances and bonuses, productivity bonuses, overtime, fringe benefits, and in kind benefits). Some forms of remuneration are excluded such as overtime (because one aspect of the definition of a living wage is that it should be earned in normal working time) and deferred benefits (because they are not available to pay for ongoing living expenses). Special rules are provided for how to value in kind benefits because of their controversial nature. Information on wages disaggregated by form of remuneration is often obtainable from a CBA or from cooperating establishments. Information on average wages is almost always available from secondary sources for industries and occupations. Although average wages are rarely exactly comparable to a living wage, they are nevertheless useful to put the living wage in context.

\subsection{Selecting Study Location(s) for a Living Wage Estimate Balancing Need for Place-specific Living Wage and Advantages of Generalizable Living Wage}

Because living wage study budgets are limited, it is necessary to select areas for primary data collection judiciously. The decision on where to collect primary data on food prices and housing costs needs to balance the need 
for (i) a living wage to be place-specific, (ii) advantages of being able to generalize a living wage estimate to larger areas, and (iii) limited budgets for fieldwork. It is neither practical nor desirable to have a different living wage for every small area or neighborhood, partly because workers can commute to work and partly because of implication for study costs. In addition, secondary data are usually only available for large areas such as all rural areas or all urban areas. It should always be kept in mind that a living wage is the same for all workers in a geographic area and it is not situational and does not vary by establishment.

To decide on where to collect local area primary data, researchers should start by drawing a map of the study area or city and indicate on it where factories or farms are concentrated, along with number of factories and number of workers in each location. Such information can be obtained from local key informants, establishment registers, standard setting organizations, and sponsors of a living wage study. Based on this information, discussions with sponsoring agencies and key informants and possibly a scoping visit, the researcher should select the geographic area or areas for primary data collection that best reflect and represent living costs for typical workers. Once a geographic area or areas are selected, specific locations to collect primary data on food prices and housing costs should be purposefully selected.

\subsubsection{Selecting study locations for industries that produce agricultural commodities}

Agricultural commodities such as tea, coffee, cocoa, etc. are generally grown over very large geographic regions. Primary data should be collected in regions that are typical of the larger geographical area in which the commodity is produced, so that the living wage estimate is representative of the area as a whole. In Malawi, we collected primary data in two large districts in Southern Malawi where most tea plantations are located. In Kenya, we collected primary data in the area around Lake Naivasha where most flower farms are located. In South Africa where the wine grape growing area covers several hundred kilometers, we selected a single typical area that was considered by local key informants as having typical prices and living costs for the wine grape growing region.

\subsubsection{Selecting study locations for factories and industries}

Export-oriented factories in developing countries are generally concentrated in particular areas of cities, often in industrial zones located in the city outskirts where costs are lower. This means that living costs for factory workers are usually lower than living costs for the city as a whole and especially for the city center. 
A living wage for factory workers should be based on local food and housing costs for areas that are representative of where factory workers live with two provisos. Locations should be within reasonable commuting distance, and slums should be excluded because they are not decent places to live. For example, many garment factories in Dhaka, Bangladesh, are concentrated in the Mirpur district of Dhaka and in separate satellite cities in the greater metropolitan area. Electronics factories in Shanghai are located in the outskirts of the city. Factories in Santo Domingo, Phnom Penh, Nagpur, and a second tier city in Vietnam where we have estimated living wages are concentrated in industrial zones just outside each of these cities with workers generally commuting short distances. In Johannesburg, we found that factory workers commuted from separate townships such as Soweto that are themselves separate cities as Soweto has more than 1 million persons. These examples illustrate that there is considerable variation across countries and cities in where factories are located and factory workers live.

\section{NOTE}

1. In locations where rental markets are not well developed, such as in many rural areas, the user cost of owner-occupied housing is used to estimate local housing costs. 


\section{APPENDIX 2.1}

\section{Table 2A.1 Use of primary and secondary data for estimating a living wage}

Cost Use of primary and secondary data

\section{Food costs}

1. Required number of calories

2. Model diet

3. Local food prices

\section{Housing costs}

1. Local housing standard

2. Cost of acceptable local housing
a. Rent

\section{Primary data}

$\underline{\text { Secondary data }}$

Excel living wage calorie calculator program is used (based on WHO equations).

Inputs are needed on average adult height (secondary data), reference family size (see below), and assumptions of physical activity levels of adults and children.

\section{Primary and secondary data}

Excel living wage model diet program is used.

\section{Primary data}

Local market survey (see below) to determine food prices and identify common low-cost foods to represent each food group in model diet.

Secondary data

Other model diets and/or reported food consumption (e.g. from poverty line, nutritionists, household surveys, FAOSTAT); nutritional content and percentage inedible of each food; percentage distribution of food expenditure from another source used only as a check on the model diet.

Primary and secondary data

Primary data

Local food market survey.

Secondary data

Monthly food price data from another source and research articles to determine possible seasonality of food prices.

\section{Primary and secondary data \\ Secondary data \\ International minimum standards, local housing conditions from household surveys and registers, and local housing standards from governments and NGOs. \\ Primary data \\ Discussions with workers and key informants to possibly modify local housing standard.}

Rent for acceptable local housing or user cost of owneroccupied housing in locations with small rental market. 
Table $2 A .1$ (continued)

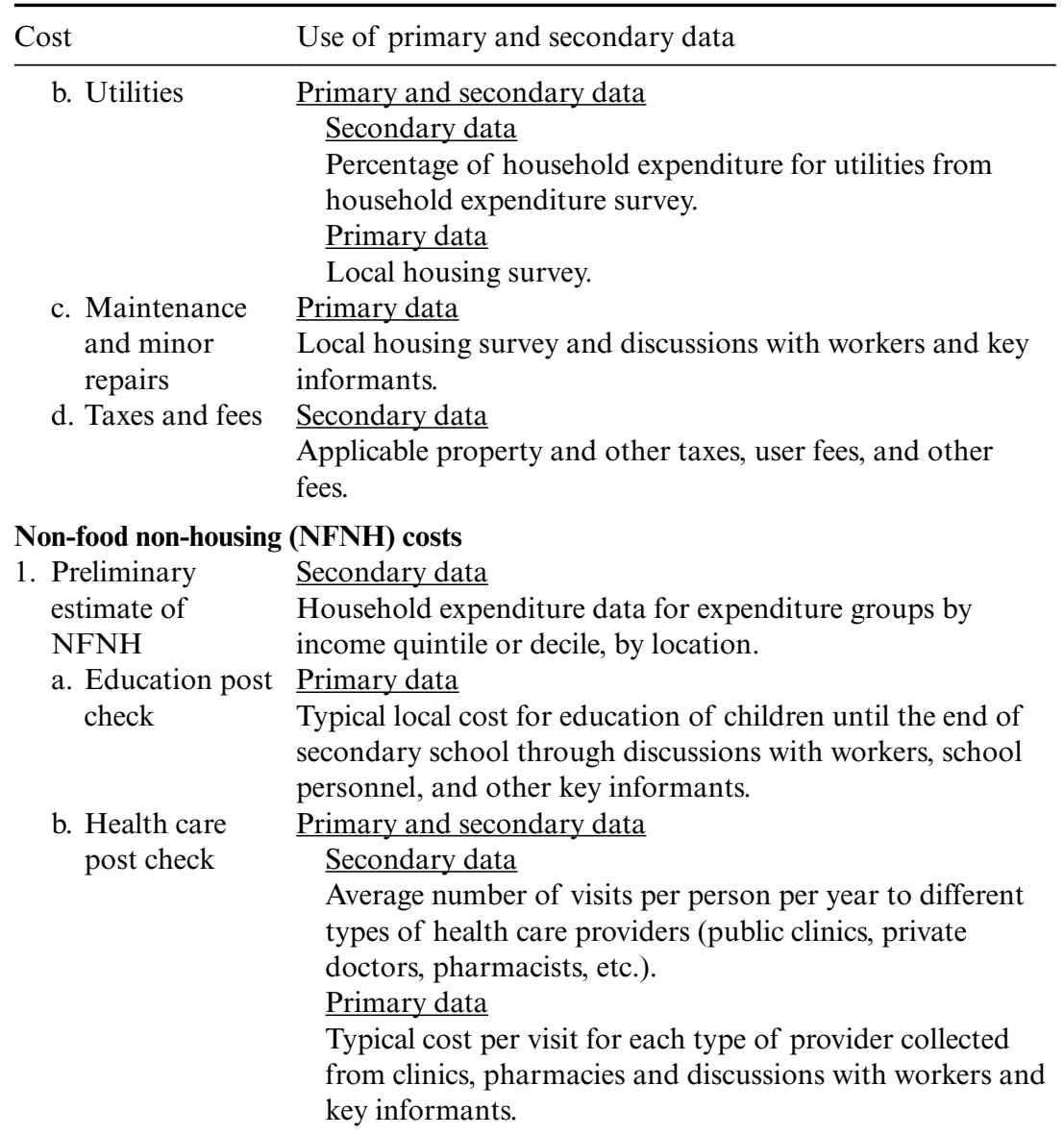

Additional funds

1. For sustainability $5 \%$ by assumption.

2. For parents Usually 0 . Otherwise by assumption usually equal to around and relatives $5 \%$ or one day of living wage.

Number of workers per family

Secondary data

Labor force participation rates, unemployment rates, and part-time employment rates by age, sex and location.

Reference family $\quad \underline{\text { Secondary data }}$

size

Average household size, distribution of households by number of members, total fertility rate, and under 5 mortality rate. 
Table 2A.1 (continued)

\begin{tabular}{ll}
\hline Cost & Use of primary and secondary data \\
\hline $\begin{array}{l}\text { Statutory } \\
\text { deductions from } \\
\text { pay }\end{array}$ & $\begin{array}{l}\text { Secondary data } \\
\text { Information on income tax, social security taxes, union fees, } \\
\text { and other deductions from pay. }\end{array}$ \\
$\begin{array}{l}\text { 1. Prevailing } \\
\text { wages that are } \\
\text { comparable } \\
\text { to a living wage }\end{array}$ & $\begin{array}{l}\text { Primary data } \\
\text { Payroll data from individual establishments. } \\
\text { employer. } \\
\text { Cost of each common in kind benefit to employer, market } \\
\text { value, replacement cost to workers. } \\
\text { Collective bargaining agreements (CBAs). } \\
\text { Secondary data }\end{array}$ \\
& $\begin{array}{l}\text { Average prevailing wages for relevant occupations and } \\
\text { industries. } \\
\text { Minimum wages. }\end{array}$ \\
& $\begin{array}{l}\text { Poverty line wages. } \\
\text { Other living wage estimates from unions, NGOs, government. }\end{array}$ \\
&
\end{tabular}

